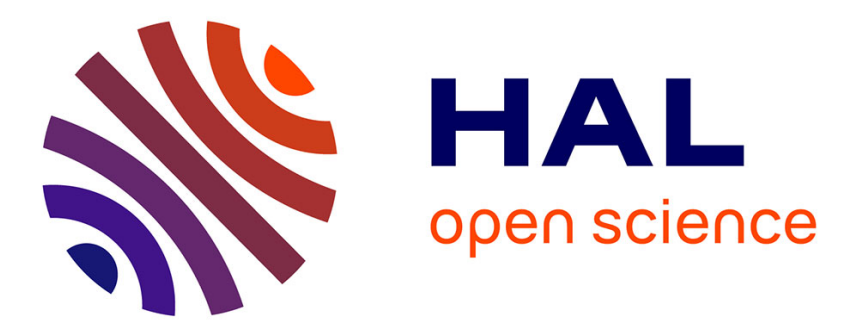

\title{
Simulation of aerosol radiative properties with the ORISAM-RAD model during a pollution event (ESCOMPTE 2001)
}

Marc Mallet, Véronique Pont, Catherine Liousse, Jean-Claude Roger, Philippe Dubuisson

\section{To cite this version:}

Marc Mallet, Véronique Pont, Catherine Liousse, Jean-Claude Roger, Philippe Dubuisson. Simulation of aerosol radiative properties with the ORISAM-RAD model during a pollution event (ESCOMPTE 2001). Atmospheric environment, 2006, 40, pp.7696-7705. 10.1016/j.atmosenv.2006.08.031 . hal00138867

\section{HAL Id: hal-00138867 https://hal.science/hal-00138867}

Submitted on 8 Jul 2021

HAL is a multi-disciplinary open access archive for the deposit and dissemination of scientific research documents, whether they are published or not. The documents may come from teaching and research institutions in France or abroad, or from public or private research centers.
L'archive ouverte pluridisciplinaire HAL, est destinée au dépôt et à la diffusion de documents scientifiques de niveau recherche, publiés ou non, émanant des établissements d'enseignement et de recherche français ou étrangers, des laboratoires publics ou privés.

\section{(c)(1) $\$$}

Distributed under a Creative Commons Attribution - NonCommercial| 4.0 International 


\title{
Simulation of aerosol radiative properties with the ORISAM-RAD model during a pollution event (ESCOMPTE 2001)
}

\author{
M. Mallet ${ }^{\mathrm{a}, *}$, V. Pont ${ }^{\mathrm{a}}$, C. Liousse ${ }^{\mathrm{a}}$, J.C. Roger $^{\mathrm{b}}$, P. Dubuisson $^{\mathrm{b}}$ \\ a Laboratoire d'Aerologie/OMP, UMR 5560 CNRS-UPS, 14, av. E. Belin, 31400 Toulouse, France \\ ${ }^{\mathrm{b}}$ LOCL/MREN-UMR CNRS ELICO 8013, Université du Littoral Côte d'Opale, France
}

\begin{abstract}
The aim of this study is to present the organic and inorganic spectral aerosol module-radiative (ORISAM-RAD) module, allowing the 3D distribution of aerosol radiative properties (aerosol optical depth, single scattering albedo and asymmetry parameter) from the ORISAM module. In this work, we test ORISAM-RAD for one selected day (24th June) during the ESCOMPTE (expé rience sur site pour contraindre les mode' les de pollution atmosphé rique et de transport d'emissions) experiment for an urban/industrial aerosol type. The particle radiative properties obtained from in situ and AERONET observations are used to validate our simulations. In a first time, simulations obtained from ORISAM-RAD indicate high aerosol optical depth (AOD) $\sim 0.50-0.70 \pm 0.02$ (at $440 \mathrm{~nm}$ ) in the aerosol pollution plume, slightly lower $(\sim 10-20 \%)$ than AERONET retrievals. In a second time, simulations of the single scattering albedo $\left(\omega_{\mathrm{o}}\right)$ have been found to well reproduce the high spatial heterogeneities observed over this domain. Concerning the asymmetry parameter $(g)$, ORISAM-RAD simulations reveal quite uniform values over the whole ESCOMPTE domain, comprised between $0.61 \pm 0.01$ and $0.65 \pm 0.01$ (at $440 \mathrm{~nm}$ ), in excellent agreement with ground based in situ measurements and AERONET retrievals. Finally, the outputs of ORISAM-RAD have been used in a radiative transfer model in order to simulate the diurnal direct radiative forcing at different locations (urban, industrial and rural). We show that anthropogenic aerosols strongly decrease surface solar radiation, with diurnal mean surface forcings comprised between $-29.0 \pm 2.9$ and $-38.6 \pm 3.9 \mathrm{Wm}^{-2}$, depending on the sites. This decrease is due to the reflection of solar radiations back to space $\left(-7.3 \pm 0.8<\Delta F_{\mathrm{TOA}}<-12.3 \pm 1.2 \mathrm{Wm}^{-2}\right)$ and to its absorption into the aerosol layer $\left(21.1 \pm 2.1<\Delta F_{\mathrm{ATM}}<26.3 \pm 2.6 \mathrm{Wm}^{-2}\right)$. These values are found to be consistent with those measured at local scale.
\end{abstract}

Keywords: Aerosol model; Aerosol radiative properties; Direct radiative forcing

\footnotetext{
*Corresponding author. Tel.: + 33561332741 ; fax: +33561332790 .

E-mail address: malm@aero.obs-mip.fr (M. Mallet).
}

\section{Introduction}

It is now clearly recognized that anthropogenic and natural aerosol particles represent one of the largest source of uncertainty on the estimation of future climate (IPCC, 2001). Indeed, in contrast 
with the radiative forcing due to greenhouse gases that can be determined to a reasonably high degree of accuracy, the uncertainties related to aerosol radiative forcings remain very large (IPCC, 2001). This is mainly due to the complexity of aerosols: atmospheric particles have different sizes, shapes, sources, chemical compositions and lifetimes, which makes it difficult to get an accurate global picture of the aerosol spatial and temporal distributions. Hence, in order to improve our knowledge of the aerosol climatic effect, it is crucial to develop aerosol models able to simulate the temporal and spatial evolution of aerosol physical, chemical and radiative properties.

The aim of this study is to present the organic and inorganic spectral aerosol module-radiative (ORISAM-RAD) module, allowing the determination of the key aerosol radiative properties, generally used in radiative transfer models. The base of this work is the ORISAM module, developed at the Laboratoire of Aerologie (Bessagnet and Rosset, 2001; Liousse et al., 2005 and Cousin et al., 2005) and implemented on-line within the 3D mesoscale non-hydrostatic chemistry model (MESO-NH-C). ORISAM allows simulating the evolution of aerosol size distribution and chemical composition under the hypothesis of internally mixed particles. The associated radiative module developed here enables computing radiative properties from ORISAM outputs.

In order to test ORISAM-RAD, we used the field campaign ESCOMPTE (experiments to constrain models of atmospheric pollution and transport of emissions) (Cros et al., 2004; Cachier et al., 2005), which took place in the south-east of France between 4th June and 13th July 2001. The ESCOMPTE domain covers the urban area of Marseille and the industrial complex of Fos-Berre (Cros et al., 2004). Due to urban and industrial emissions associated with strong solar radiation (reduced cloud covers), high and frequent pollution events are observed in this area during summer periods, leading to strong aerosol loading. Furthermore, the ESCOMPTE program results in an exhaustive set of aerosol radiative properties and represents an appropriate area for studying the capacity of ORISAM-RAD to simulate aerosol radiative properties.

Due to high computational costs of the Meso-NH$\mathrm{C}$, mainly explained by the on-line coupling of the ORISAM module and the gas-phase chemical module ReLACS (Crassier et al., 2000), we focus our investigations for one selected day (24th June 2001).
This episode represents one of the most polluted days during ESCOMPTE and we used previous ORISAM simulations performed by Cousin et al. (2005) for this day. The model configuration (spin-up, spatial, temporal resolution, chemical initialization), the meteorological conditions and the emission inventories used in simulations are not recalled here. All these informations are well described in detail by Cousin et al. (2005). In this paper, we focused on the ORISAM-RAD module description and on the results we obtained concerning aerosol optical depths, asymmetry parameters and direct radiative forcings. Aerosol single scattering albedos simulations have been presented previously (Mallet et al., 2005b) and the main results are just recalled here.

\section{Description of the ORISAM-RAD module}

\subsection{Modelling of aerosol physical and chemical properties: the ORISAM module}

The base of ORISAM-RAD is the ORISAM module, which has been developed by Bessagnet and Rosset (2001) at the laboratory of Aerologie in order to simulate the evolution of aerosol size distribution and chemical composition. In ORISAM, the sectional approach was retained for its flexibility in solving aerosol multicomponent systems and its ability to well describe the microphysical processes. The sectional representation discretizes the particle size distribution in a finite number of bins. In each section (i), all particles have the same composition and are characterized by their mean diameter $d_{i}$. In ORISAM, the aerosol size distribution comprises four bins with diameters ranging from 0.03 to $10 \mu \mathrm{m}$ (Fig. 1). ORISAM takes into account the processes of nucleation, coagulation, condensation, adsorption, chemical reaction and deposition. A detailed description can be found in Bessagnet et al. (2004).

In ORISAM, six chemical species are considered; anthropogenic primary carbon, secondary organic carbon, sulphates, nitrates $\left(\mathrm{NO}_{x}\right.$ oxidation in the gas phase and heterogeneous chemistry), ammonium (neutralization by nitric and sulphuric acids in the aerosol phase) and water. Primary carbonaceous aerosol has been partitioned into black carbon (BC) and primary organic carbon $\left(\mathrm{OC}_{\mathrm{p}}\right)$ to account for their different physical and radiative properties and secondary organics have been partitioned into the anthropogenic fraction secondary organic aerosol anthropogenic (SOAA) and the biogenic one 


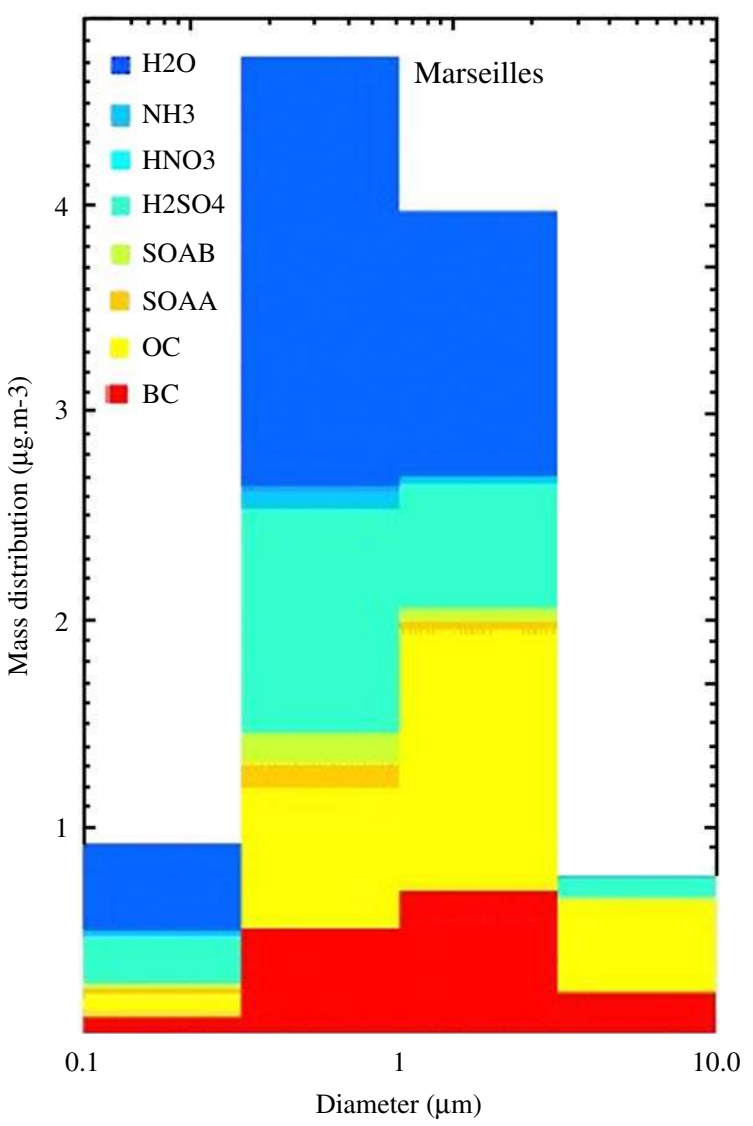

Fig. 1. Aerosol size distributions modelled by ORISAM (organic and inorganic spectral aerosol module) at 12 UTC at Marseille.

secondary organic aerosol biogenic (SOAB). Primary organic matter $\left(\mathrm{OM}_{\mathrm{p}}\right)$ concentrations were calculated from the concentrations of primary organic carbon using a constant conversion factor (Liousse et al., 1996) and secondary organic components $\left(\mathrm{OM}_{\mathrm{s}}\right)$ were obtained by adding the concentrations of SOAA and SOAB.

\subsection{Modelling of aerosol radiative properties: the ORISAM-RAD module}

In ORISAM-RAD, the extinction $\left(Q_{\text {ext }}\right)$, scattering $\left(Q_{\text {scat }}\right)$, absorption $\left(Q_{\text {abs }}\right)$ and radiation pressure $\left(Q_{\mathrm{pr}}\right)$ efficiencies of a single particle, are computed using the $n$-layer spheres algorithm of $\mathrm{Wu}$ and Wang (1991) and the radiative properties of the total aerosol population $\left(K_{\text {ext }}, K_{\text {scat }}, K_{\text {abs }}\right.$ and $\left.K_{\mathrm{pr}}\right)$ by using the methodology reported by $\mathrm{Wu}$ et al. (1996) for a sectional approach. The aerosol optical depth (AOD) is obtained through the integration of the extinction coefficient $K_{\text {ext }}$, between the surface and the top of the atmosphere. The single scattering albedo (SSA) is obtained as the ratio of the total aerosol scattering $K_{\text {scat }}$ to the sum of $K_{\text {scat }}$ and $K_{\text {abs }}$ and the asymmetry parameter $(g)$ is computed using the relation given by Hoekstra et al. (2001):

$g=\left(K_{\text {ext }}-K_{\text {pr }}\right) / K_{\text {scat }}$.

In ORISAM-RAD, the aerosol is assumed to be composed of three concentric different layers. This treatment of aerosol mixing in ORISAM-RAD is supported by the work of Jacobson (2000), which indicates that the well-mixed internally treatment is unphysical as soot, which contains BC, is mostly solid and can not be "well-mixed" in the particle. He suggests also that the core treatment may be more representative than the external-mixture treatment. In our simulations, black carbon is assumed to be the core and primary organics are assumed to form the first shell around the black carbon core. Finally, the third layer is assumed to be composed by all water soluble hydrophilic components as ammonium sulphates, nitrates and $\mathrm{OM}_{\mathrm{s}}$, in solution in water. This well represents particles of pollution as aerosols emitted from fossil-fuel combustion contain black carbon covered with a layer of polycyclic aromatic hydrocarbons (PAHs) under a shell of volatile compounds (Steiner et al., 1992). Once emitted, particles may coagulate and/or grow by condensation of water, inorganics and secondary organics (sulphates, nitrates and $\mathrm{OM}_{\mathrm{s}}$ ).

One major advantage of ORISAM-RAD lies in the distinction between primary and secondary organic components. This allows, in this case, different relationships between optical properties of each aerosol with the relative humidity. In our simulation, we assume primary components $\left(\mathrm{OM}_{\mathrm{p}}\right)$ as hydrophobic and secondary $\left(\mathrm{OM}_{\mathrm{s}}\right)$ as hydrophilic. The refractive indexes used in our simulations for each component are reported in Mallet et al. (2005b). Sensitivity tests on the choice of the black carbon refractive index are presented in section 4.1. The real and imaginary parts of the third layer have been determined using a volume average procedure (Lesins et al., 2002) for all water soluble components. The aerosol refractive indexes of hydrophilic aerosols have been computed at the ambient relative humidity $\left(m_{\mathrm{i}(\mathrm{h})}\right)$ using the relation of Hänel (1976):

$m_{\mathrm{i}(\mathrm{h})}(\lambda)=m_{\mathrm{H}_{2} \mathrm{O}}(\lambda)+\left(m_{\mathrm{i}(\mathrm{O})}(\lambda)-m_{\mathrm{H}_{2} \mathrm{O}}(\lambda)\right)\left(\frac{r_{\mathrm{g}, n(\mathrm{i})(\mathrm{h})}}{r_{\mathrm{g}, n(\mathrm{i})(\mathrm{O})}}\right)^{-3}$, 
where $m_{\mathrm{H}_{2} \mathrm{O}}$ is the pure water refractive index, $m_{\mathrm{i}(\mathrm{O})}$ the refractive index of the aerosol specie (i) in dry state (generally referenced in the literature), $r_{\mathrm{g}, n(\mathrm{i})(\mathrm{h})}$ and $r_{\mathrm{g}, n(\mathrm{i})(\mathrm{O})}$, respectively, the geometric modal radius (for a number size distribution) in wet and dry state.

\section{In situ aerosol radiative properties observed during the 24th June}

\subsection{Ground-based measurements}

To validate ORISAM-RAD, we firstly used aerosol radiative properties (SSA, $g$ ) computed from in situ measurements on the Vallon d'Ol site (periurban site near Marseille) by Mallet et al. (2003, 2004). In these studies, mass size distributions deduced from concentrations measured on impactor was fitted with a lognormal function from which the mass mode radius $\left(r_{\mathrm{g}, \mathrm{m}}\right)$ and the standard deviation $(\sigma)$ were retrieved. Then, the "mass" $\left(r_{\mathrm{g}, \mathrm{m}}, \sigma, M_{\mathrm{i}}\right)$ parameters were transformed into "number" parameters $\left(r_{\mathrm{g}, n}, \sigma, N_{\mathrm{i}}\right)$ according to Seinfeld and Pandis (1998) relations in order to be used in the Mie theory (1908). Computations for the 24th June indicated a single scattering albedo equals to 0.75 at this location and the asymmetry parameter equals to 0.60 .

\subsection{AERONET retrievals}

AERONET observations have been shown capable to detect important variations of both magnitude and spectral dependence of aerosol radiative properties that are consistent with aerosol type and emission conditions (Dubovik et al., 2002). Thus, apart from the surface measurements, we also used aerosol radiative properties deduced from automatic sun tracking photometers, which performed sky radiance and direct solar irradiance measurements over Marseille, Avignon, Realtor and Vinon at 440,670, 870 and $1020 \mathrm{~nm}$ wavelengths during
ESCOMPTE. The AERONET retrievals rely on Dubovik and King (2000) inversion algorithm deriving the aerosol size distribution and refractive index, which are used to calculate the aerosol single scattering albedo and asymmetry parameter for the whole atmospheric column. The accuracy of individual aerosol properties retrieval from the measurements of CIMEL radiometers was analysed in extensive sensitivity simulations (Dubovik et al., 2000).

\section{Simulation of ORISAM-RAD}

\subsection{Sensitivity tests}

This part investigates errors on aerosol radiative properties, on bottom of atmosphere (BOA), top of atmosphere (TOA) and atmospheric (ATM) forcings, generated by the hypotheses used in our simulations. We focused our simulations on the BOA (or surface), TOA and ATM aerosol radiative forcing. The first one represents the effect of particles on the net short-wave radiation fluxes at the surface; the second one, the radiation fluxes reflected to space by aerosols and the last one, the absorption of solar radiation within the atmosphere due to absorbing particles. BOA and TOA forcings have been calculated as the difference between the fluxes computed at surface and at the top of atmosphere, respectively, with and without aerosols. The atmospheric forcing has been computed as the difference between the TOA and BOA forcing. Thus, with this convention, a negative sign of $\Delta \mathrm{F}$ implicates that aerosols produce a cooling effect and vice versa.

We have performed sensitivity tests for Marseille at 12:00 UTC. Results are shown in Table 1. The major assumptions performed in this study and needed to be tested concern uncertainties on BC refractive index and density, but also on the surface albedo $\left(R_{\mathrm{S}}\right)$ estimated from the MODIS sensor

Table 1

Simulated aerosol radiative properties (at $440 \mathrm{~nm}$ ) and direct radiative forcing at Marseille (12:00 UTC) for several cases. Case 1 refers to $\rho_{\mathrm{BC}}=1.25 \mathrm{~g} \mathrm{~cm}^{-3}$, a BC visible complex refractive index of 1.87-0.569i (Marley et al., 2001) and $R_{\mathrm{s}}=0.04$

\begin{tabular}{lllllll}
\hline Case & AOD & SSA & $g$ & $\Delta F_{\mathrm{BOA}}\left(\mathrm{W} \mathrm{m}^{-2}\right)$ & $\Delta F_{\mathrm{ATM}}\left(\mathrm{W} \mathrm{m}^{-2}\right)$ & $\Delta F_{\mathrm{TOA}}\left(\mathrm{W} \mathrm{m}^{-2}\right)$ \\
\hline Case 1 & 0.31 & 0.71 & 0.65 & -57 & 50 & -7 \\
Case 1 with $m_{\mathrm{BC}}=1.95-0.66 \mathrm{i}$ & 0.31 & 0.70 & 0.64 & -57 & 50 & -7 \\
Case 1 with $r_{\mathrm{BC}}=1.75 \mathrm{~g} \mathrm{~cm}^{-3}$ & 0.30 & 0.75 & 0.66 & -56 & 48.5 & -7.5 \\
Case 1 with $+15 \%$ on $R_{\mathrm{s}}$ & 0.31 & 0.71 & 0.65 & -57 & 51 & -6 \\
Case 1 with $-15 \%$ on $R_{\mathrm{s}}$ & 0.31 & 0.71 & 0.65 & -57 & 49 & -8 \\
\hline
\end{tabular}


(Vermote et al., 1997). Concerning the BC density, we tested the value of $1.75 \mathrm{~g} . \mathrm{cm}^{-3}$, which is comprised between the value of $1.25 \mathrm{~g} \mathrm{~cm}^{-3}$ (Horvath, 1995) used in our simulations and the one of $2.25 \mathrm{~g} \mathrm{~cm}^{-3}$ (Hess and Herd, 1993) well known for pure crystalline graphite. Concerning the $\mathrm{BC}$ refractive index, we tested the value of 1.95-0.66i (Bergstrom, 1972), which is comprised between the value used in our simulations (Marley et al., 2001; see Table 1) and the one (2.00-1.00i from Hess and Herd, 1993), representative of pure crystalline graphite. Finally, concerning the surface albedo, we used the work of Roger et al. (2006), which indicates an error of about $15 \%$.

First, the results (Table 1) denote that aerosol direct forcing is more sensitive to $\mathrm{BC}$ aerosol density than to $\mathrm{BC}$ refractive index. Indeed, when a density of $1.75 \mathrm{~g} \mathrm{~cm}^{-3}$ is used instead of $1.25 \mathrm{~g} \mathrm{~cm}^{-3}$, SSA increases from 0.71 to 0.75 (at $440 \mathrm{~nm}$ ), decreasing by 2 and $3 \%$, respectively, the surface and ATM forcing, and increasing the TOA forcing by $7 \%$. Secondly, these results indicate that uncertainties upon surface albedo retrievals only affect ATM and TOA forcings. Indeed, when surface albedo is increased by $15 \%$, ATM forcing increases by $2 \%$ and the TOA decreases by $10 \%$. For a $15 \%$ decrease in $R_{\mathrm{s}}$, ATM forcing decreases by $2 \%$ and TOA forcing increases by $10 \%$. It is also found that uncertainties in $R_{\mathrm{s}}$ do not affect the BOA forcings (Table 1), contrary to observations reported by Hatzianastassiou et al. (2004), which have shown that modifications of $R_{\mathrm{s}}$ can slightly affect surface aerosol forcing. This could be due to the low surface reflectivity over the ESCOMPTE domain (for example, $R_{\mathrm{s}} \sim 0.05$ at $550 \mathrm{~nm}$ at Vinon-sur-Verdon). To summarize, the sensitivity tests indicate that one can reasonably consider uncertainties of 0.02 on AOD, 0.04 on SSA, 0.01 on $g$ (at $440 \mathrm{~nm}$ ) and $2-3 \%$ for BOA and ATM forcings and about more than $10 \%$ for TOA forcing.

\subsection{Aerosol optical depth and single scattering albedo}

Simulated geographical distributions of AOD (at $440 \mathrm{~nm})$ are reported in Fig. 2. First, as observed by Cousin et al. (2005), we can note the transport of aerosols over land occurring during the afternoon due to the establishment of the sea-breeze regime. The anthropogenic aerosol plume coming from Marseille/
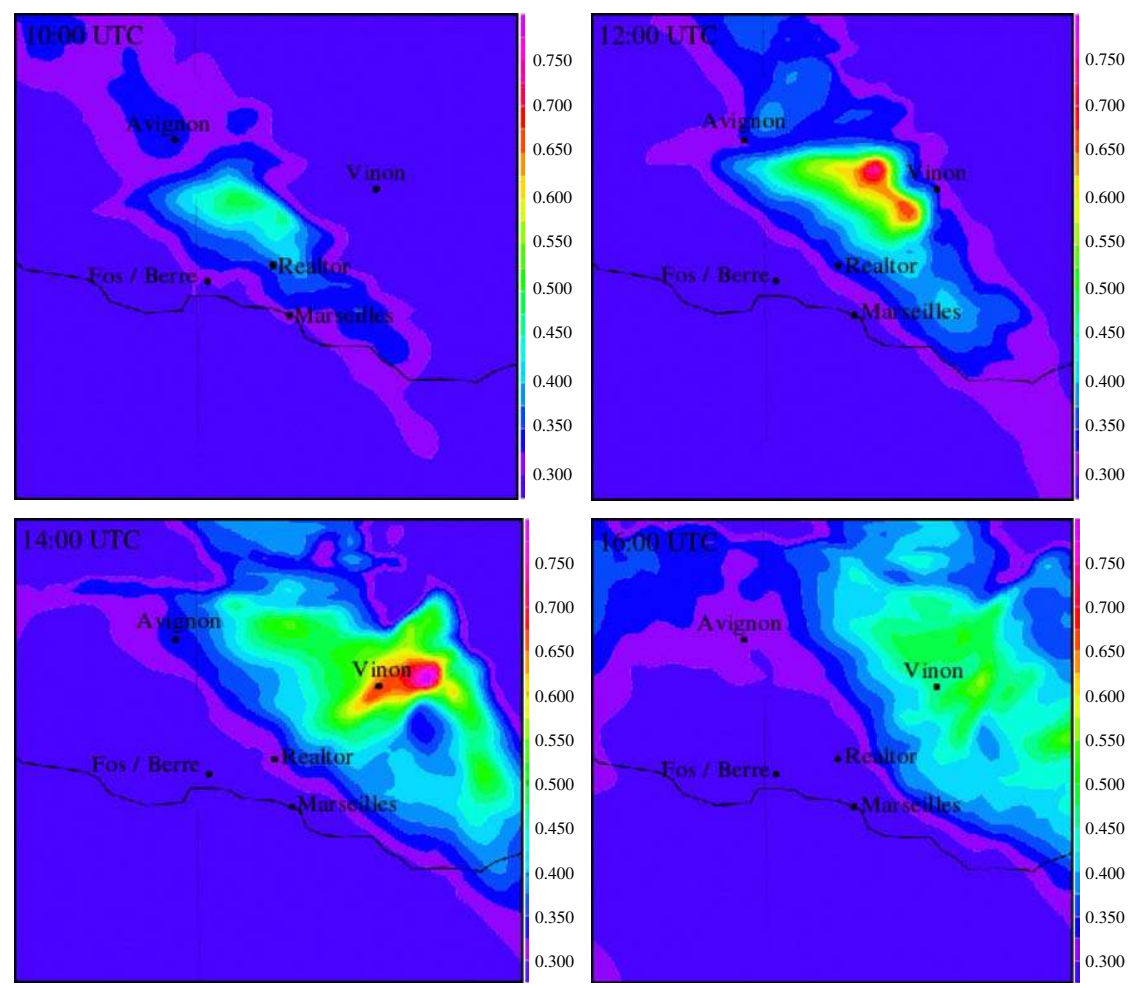

Fig. 2. Simulations of aerosol optical depth (at $440 \mathrm{~nm}$ ) at 10:00, 12:00, 14:00 and 16:00 UTC over the ESCOMPTE domain, for 24th June 2001. 



Fig. 3. Comparisons between AOD (at $440 \mathrm{~nm}$ ) retrieved from AERONET and those simulated using ORISAM-RAD at Marseille and Realtor on 24th June 2001.

Berre area is clearly observed, with high AOD about $0.50-0.70 \pm 0.02$ within the plume. In order to compare our AOD simulations with in situ measurements, we have used AERONET photometers installed at Marseille and Realtor sites. Results are shown in Fig. 3. Concerning Realtor, simulated AOD are consistent with those measured from AERONET, except at 12:00 UTC. At Marseille, some differences are observed and simulations obtained from ORISAM-RAD under-estimate AOD by $10-20 \%$, which could implicate an under-estimation of the direct radiative forcing at Marseille. To reduce these differences in AOD modelling, further improvements are presently brought to ORISAM, mainly on the gas chemical scheme for better production of secondary organic species (Cousin et al., 2005) and on the implementation of dust and sea salt production.

Concerning SSA (Mallet et al., 2005b), simulated surface SSA (at $440 \mathrm{~nm}$ ) are about $0.90-0.95 \pm 0.04$ within the Fos/Berre plume (denoting weakly absorbing aerosols) and 0.70-0.75 \pm 0.04 at Marseille (strong absorbing particles). These estimations have been shown to be quite consistent with in situ surface and aircraft measurements (Mallet et al., 2005a).

\subsection{Aerosol asymmetry factor}

The simulation of the asymmetry factor $(g)$ at the surface and at $440 \mathrm{~nm}$ is reported in Fig. 4 (at 12:00 UTC). We observe quite uniform values over the whole ESCOMPTE domain, comprised between $0.61 \pm 0.01$ and $0.65 \pm 0.01$ over land. Such a regional homogeneity is due to the fact that $g$ is mostly dependent on the aerosol size, mainly



Fig. 4. Surface simulated aerosol asymmetry factor (at $440 \mathrm{~nm}$ ) at 12:00 UTC for 24th June 2001.

observed in the submicronic range over the ESCOMPTE domain (Cachier et al., 2005). We also observe good agreement with the AERONET retrievals, which give values of $0.66 \pm 0.04$ at Marseille and Avignon, $0.63 \pm 0.04$ at Vinon and $0.66 \pm 0.04$ at Realtor. Finally, Mallet et al. (2003) indicated a value of $0.60 \pm 0.04$, from Mie (1908) computations at the surface near Marseille, thus showing close agreement between simulations and experimental results.

\section{Simulation of the aerosol direct radiative forcing for different locations}

\subsection{Estimation of the aerosol direct forcing}

At the present time, ORISAM-RAD is not coupled "on-line" with the global atmospheric 
ModEl (GAME) (Dubuisson et al., 2004), Radiative Transfer Model (RTM), due to its high computational costs and we can not compute the regional direct forcing. However, we took advantage of our ORISAM-RAD simulations to simulate the radiative forcing at four different pertinent locations. We chose two "urban" sites (Marseille and Avignon), one "industrial" (Realtor), located near the industrial complex of Fos-Berre and one "rural" (Vinonsur-Verdon), located $50 \mathrm{~km}$ inland, which could be affected by the pollution plume developed over the Marseille/Berre region.

The RTM GAME accounts for the scattering and absorption processes by particles and gazes. In GAME, the absorption includes the absorbers in the short-wave region and is based on the results of a line by line code (Scott, 1974). Multiple scattering effects are treated using the discrete ordinates method (DOM) (Stamnes et al., 1988) following the plane-parallel approximation. This method allows accurate treatment of scattering and absorption by aerosols, clouds and molecules. The DOM employs a Legendre polynomial decomposition for the phase function and the radiance. Gaseous absorption $\left(\mathrm{H}_{2} \mathrm{O}, \mathrm{CO}_{2}, \mathrm{O}_{2}\right.$ and $\left.\mathrm{O}_{3}\right)$ is treated from the correlated $k$-distribution (Lacis and Oinas, 1991). Radiative fluxes are calculated in the spectral range of $2500-50000 \mathrm{~cm}^{-1}(0.2-4 \mu \mathrm{m})$, with a $100 \mathrm{~cm}^{-1}$ spectral resolution. It should be noted that aerosol radiative properties simulated by ORISAM-RAD between the surface and $4000 \mathrm{~m}$ height have been completed with the Hess et al. (1998) aerosol models for the free troposphere and stratosphere. The vertical profiles of relative humidity and ozone concentration used in GAME have been measured from aircraft soundings during ESCOMPTE.

\subsection{Results}

Results of simulations of the instantaneous aerosol direct radiative forcing (BOA, TOA and ATM) are presented for Marseille, Realtor, Vinon and Avignon at 10:00, 12:00, 14:00 and 16:00 UTC (Fig. 5). First, it can be noticed that the presence of anthropogenic aerosols reduces surface solar radiations at the four different sites. Indeed, we have observed large instantaneous surface forcings for different computed hours whatever the sites studied, with values ranging between $-48 \pm 5$ and $-112 \pm 10 \mathrm{~W} \mathrm{~m}^{-2}$. In particular, we have noted a uniform surface forcing $\left(-60 \pm 6 \mathrm{~W} \mathrm{~m}^{-2}\right)$ at 12:00 UTC.
These results also highlight that maximum surface forcing does not occur near the pollution sources but in rural areas. Indeed, under the sea-breeze circulation, aerosol pollutants are transported inland, thus increasing aerosol concentrations and AOD in rural zones. Therefore, a higher instantaneous surface forcing may be retrieved (Fig. 5) at Vinon in the afternoon $\left(-110 \pm 10 \mathrm{~W} \mathrm{~m}^{-2}\right.$ at 14:00 UTC and $-84 \pm 8 \mathrm{~W} \mathrm{~m}^{-2}$ at 16:00 UTC), compared to the one computed at Marseille or Realtor $\left(\sim-60 \mathrm{~W} \mathrm{~m}^{-2}\right)$.

Such a study provides an additional proof of the strong impact of the aerosol chemical composition upon surface and atmospheric forcings over a polluted region. Indeed, the high concentrations of absorbing black carbon particles observed during ESCOMPTE (Cachier et al., 2005) reduce the aerosol single scattering albedo (Mallet et al., 2005a,b), thus leading to large instantaneous atmospheric forcings, ranging between $40 \pm 4$ and $83 \pm 8 \mathrm{~W} \mathrm{~m}^{-2}$ (Fig. 5).

The diurnal mean BOA forcing ranges, following the sites, between $-29.0 \pm 2.9$ and $-38.6 \pm$ $3.9 \mathrm{~W} \mathrm{~m}^{-2}$, the TOA between $-7.3 \pm 0.8$ and $-12.3 \pm$ $1.2 \mathrm{~W} \mathrm{~m}^{-2}$, and the ATM between $21.1 \pm 2.1$ and $26.3 \pm 2.6 \mathrm{~W} \mathrm{~m}^{-2}$. These values are in agreement with the BOA $\left(-35.5 \pm 7.1 \mathrm{~W} \mathrm{~m}^{-2}\right)$, TOA $(-9 \pm 1.8$ $\left.\mathrm{W} \mathrm{m}^{-2}\right)$ and ATM $\left(26.5 \pm 5.3 \mathrm{~W} \mathrm{~m}^{-2}\right)$ forcings reported by Roger et al. (2006) at local scale (peri-urban site of Marseille) for the 24th June. The difference observed at Marseille is certainly due to the AOD under-estimation by ORISAM-RAD at this site (Fig. 3).

It should be noted that the simulated forcings are consistent with those reported during experimental campaigns, characterizing anthropogenic aerosols, such as TARFOX $\left(\Delta F_{\text {toa }}=-9 \mathrm{~W} \mathrm{~m}^{-2}, \Delta F_{\text {boa }}=\right.$ $-26 \mathrm{~W} \mathrm{~m}^{-2}$ and $\Delta F_{\text {atm }}=17 \mathrm{~W} \mathrm{~m}^{-2}$, from Hignett et al., 1999) or INDOEX $\left(\Delta F_{\text {toa }}=-17 \mathrm{~W} \mathrm{~m}^{-2}\right.$, $\Delta F_{\text {boa }}=-45 \mathrm{~W} \mathrm{~m}^{-2}$ and $\Delta F_{\mathrm{atm}}=28 \mathrm{~W} \mathrm{~m}^{-2}$, from Ramanathan et al., 2001; Léon et al., 2002). The difference obtained during TARFOX is due to more scattering aerosols ( $\mathrm{SSA}_{\text {TARFOX }} \sim 0.93$ ), while the larger forcings observed during INDOEX are due to higher AOD with mean $\mathrm{AOD}_{\text {INDOEX }} \sim 0.60$ (at $550 \mathrm{~nm}$ ) inside the plume spreading from India.

Finally, even if our simulations have been performed for one day, AOD close to 0.5 have often been observed during the summer 2001 over the ESCOMPTE domain. Furthermore, it must be mentioned that the number of ozone pollution days every year (always associated with high aerosol loadings) is increasing over this region of France. 

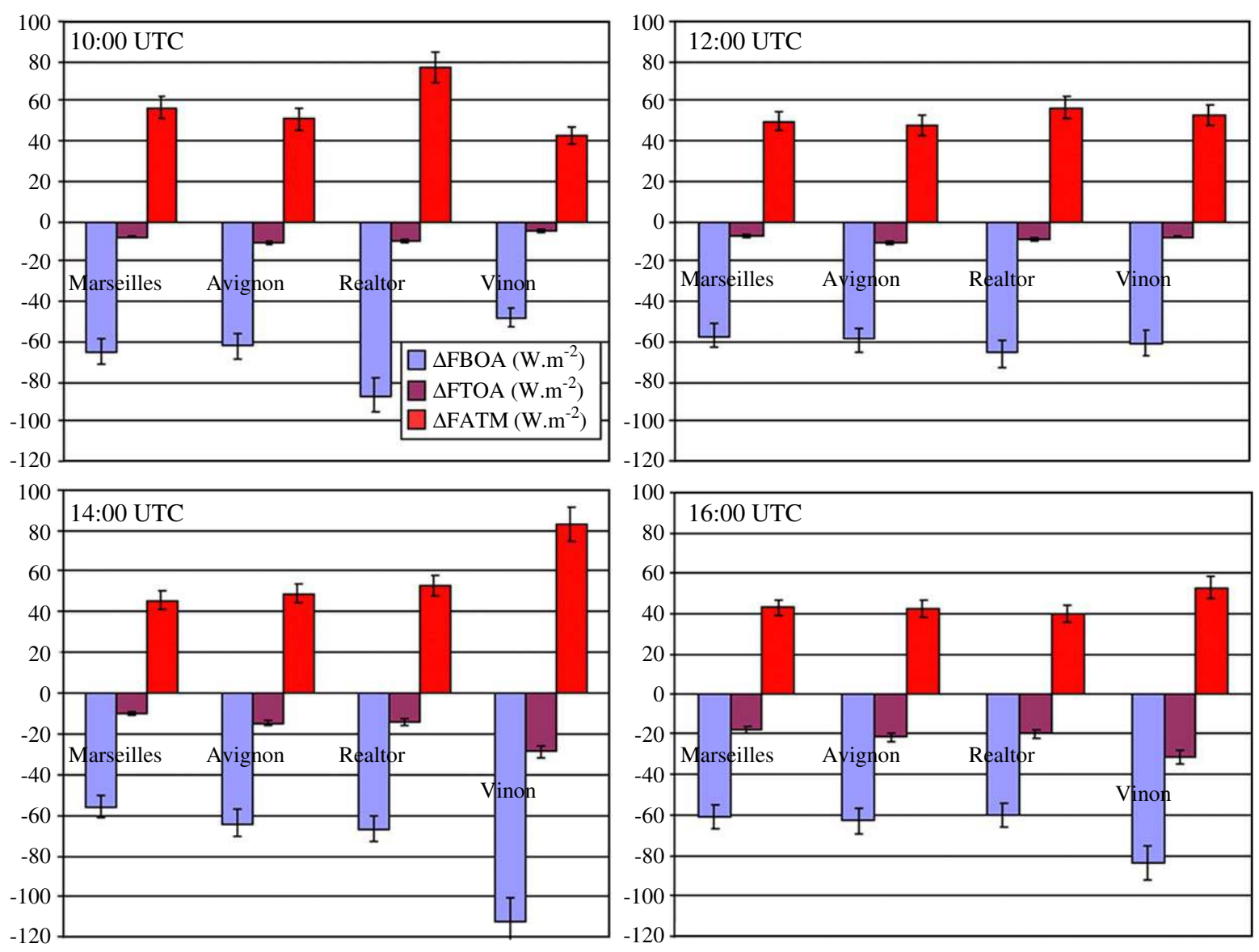

Fig. 5. Simulated instantaneous aerosol direct radiative forcing (in $\mathrm{W} \mathrm{m}^{-2}$ ) at the surface (BOA), at the top of atmosphere (TOA) and within the atmosphere (ATM) at Marseille, Realtor, Vinon and Avignon (at 10:00, 12:00, 14:00 and 16:00 UTC) for 24th June 2001.

For example, this number has increased from 30 (in 1999) to 60 (in 2003). As a consequence, the aerosol effect on the regional climate also tends to increase from year to year and if this trend persists, higher atmospheric heating can be then expected in the near future.

\section{Conclusion}

The purpose of this work is to present the organic and inorganic spectral aerosol module-radiative (ORISAM-RAD) module, developed on the Laboratoire of Aerologie. This module computes aerosol radiative properties (aerosol optical depth, single scattering albedo and asymmetry parameter) from the ORISAM module, which allows simulating the evolution of aerosol size distribution and chemical composition, under the hypothesis of internally mixed particles. In order to test ORISAM-RAD, we used previous simulations performed by Cousin et al. (2005) for one selected day (24th June) during the ESCOMPTE experiment. In-situ and AERONET observations performed for this date are used to validate our simulations. The results of ORISAM-RAD simulations firstly indicate that industrial and urban emissions lead to high aerosol optical depth (AOD) 0.50-0.70 \pm 0.02 (at $440 \mathrm{~nm}$ ) in the aerosol plume. These values are found to be slightly lower $(\sim 10-20 \%)$ than AERONET retrievals and some improvements are performed in ORISAM in order to obtain better AOD simulations. Secondly, ORISAM-RAD seems well simulating the high spatial single scattering albedo heterogeneities over the domain observed by Mallet et al. (2005a). Concerning the asymmetry parameter, we observe quite uniform values over the whole ESCOMPTE domain, comprised between $0.61 \pm 0.01$ and $0.65 \pm 0.01$ over land (at $440 \mathrm{~nm}$ ), in excellent agreement with in-situ and AERONET retrievals. Finally, the outputs of ORISAM-RAD 
have been used in a radiative transfer model to simulate the diurnal direct radiative forcing at different locations. Our results indicate that the presence of high anthropogenic aerosol concentrations leads to a large diurnal average surface forcing $(-29.0 \pm$

$2.9<\Delta \bar{F}_{\mathrm{BOA}}<-38.6 \pm 3.9 \mathrm{~W} \mathrm{~m}^{-2}$ ) for all sites studied (urban, industrial and rural). We show also that the diurnal mean surface forcing is three times larger than the TOA forcing $(-7.3 \pm$ $0.8<\Delta F_{\mathrm{TOA}}<-12.3 \pm 1.2 \mathrm{~W} \mathrm{~m}^{-2}$ ), leading to an important atmospheric forcing (21.1 \pm 2.1 $<\Delta F_{\mathrm{ATM}}<26.3 \pm 2.6 \mathrm{~W} \mathrm{~m}^{-2}$ ). These values are found to be consistent with those computed at local scale by Roger et al. (2006) or Hatzianastassiou et al. (2004) on global scale. The next step of this work is to study what could be the feedback of the anthropogenic aerosol forcing on the hydrological cycle, the cloud formation or the stability of the lower atmosphere over this domain.

\section{Acknowledgments}

The authors are indebted to Dr. Bernard Cros, Dr. Pierre Durand and Dr. H. Cachier for the organization of the ESCOMPTE experiment. We gratefully acknowledge different Institutes in France (CNRS, INSU, ADEME, Ministry of Environment) for their support. We would like also to thank F. Cousin and R. Rosset for their help during this work.

\section{References}

Bergstrom, R.W., 1972. Predictions of the spectral absorption and extinction coefficients of an urban air pollution model. Atmospheric Environment 6, 247-258.

Bessagnet, B., Rosset, R., 2001. Fractal modelling of carbonaceous aerosols - application to car exhaust plumes. Atmospheric Environment 35, 4751-4762.

Bessagnet, B., et al., 2004. Aerosol modelling with CHIMEREPreliminary evaluation at the continental scale. Atmospheric Environment 38, 2803-2817.

Cachier, H., et al., 2005. Aerosol studies during the ESCOMPTE experiment: an overview. Atmospheric Research 74, $547-563$.

Cousin, F., Liousse, C., Cachier, H., Bessagnet, B., Rosset, R., 2005. Aerosol modelling and validation during ESCOMPTE 2001. Atmospheric Environment 39 (8), 1539-1550.

Crassier, V., Suhre, K., Tulet, P., Rosset, R., 2000. Development of a reduced chemical scheme for use in mesoscale meteorological models. Atmospheric Environment 34, 2633-2644.

Cros, B., et al., 2004. An overview of the ESCOMPTE Campaign. Atmospheric Research 69 (3-4), 241-279.
Dubovik, O., King, M.D., 2000. A flexible inversion algorithm for retrieval of aerosol optical properties from Sun and sky radiance measurements. Journal of Geophysical Research 105 (D16), 20673-20696.

Dubovik, O., Smirnov, A., Holben, B.N., King, M.D., Kaufman, Y.J., Eck, T.F., Slutsker, I., 2000. Accuracy assessments of aerosol optical properties retrieved from AERONET Sun and sky-radiance measurements. Journal of Geophysical Research 105, 9791-9806.

Dubovik, O., Holben, B.N., Eck, T.F., Smirnov, A., Kaufman, Y.J., King, M.D., Tanré, D., Slutsker, I., 2002. Variability of absorption and optical properties of key aerosol types observed in worldwide locations. Journal of Atmospheric Science 59, 590-608.

Dubuisson, P., Dessailly, D., Vesperini, M., Frouin, R., 2004. Water vapor retrieval over ocean using near-infrared radiometry. Journal of Geophysical Research 109, D19106, doi:10.1029/2004JD004516.

Hänel, G., 1976. The properties of atmospheric particles as functions of the relative humidity at thermodynamic equilibrium with surrounding moist air. Advances in Geophysics $19,73-188$

Hatzianastassiou, N., Katsoulis, B., Vardavas, I., 2004. Sensitivity analysis of aerosol direct radiative forcing in ultravioletvisible wavelengths and consequences for the heat budget. Tellus B 56 (4), 368.

Hoekstra, A.G., Frijlink, M., Waters, L.B.F.M., Sloot, P.M.A., 2001. Radiative forces in the discrete-dipole approximation. Journal of the Optical Society of America A 18 (8).

Horvath, H., 1995. Size segregated light absorption coefficient of the atmospheric aerosol. Atmospheric Environment 29, 875-883.

Hess, W.H., Herd, C.R., 1993. Carbon Black. Marcel Dekker, New York.

Hess, M., Koepke, P., Schult, I., 1998. Optical properties of aerosols and clouds: the software package. Bulletin of American. Meteorological Society 79, 831-844.

Hignett, P., Taylor, J.P., Francis, P.N., Glew, M.D., 1999. Comparison of observed and modelled direct forcing during TARFOX. Journal of Geophysical Research 104, 2279-2287.

Intergovernmental Panzel on climate change. In: Houghton J.T. et al.(Eds.), Climate Change 2001.Cambridge University Press, New York.

Jacobson, Z.J., 2000. A physically-based treatment of elemental carbon optics: implications for direct forcing of aerosols. Geophysical Research Letters 27, 217-220.

Lacis, A.A., Oinas, V., 1991. A description of the correlated $k$ distribution method. Journal of Geophysical Research 96, 9027-9064.

Léon, J-F., Chazette, P., Pelon, J., Dulac, F., Randriamarisoa, H., 2002. Aerosol direct radiative forcing impact over the INDOEX area based on active and passive remote sensing. Journal of Geophysical Research 107 (D19), doi:10.1029/ 2000JD000116.

Lesins, G., Chylek, P., Lohmann, U., 2002. A study of internal and external mixing scenarios and its effect on aerosol optical properties and direct radiative forcing. Journal of Geophysical Research 107 (D10), doi:10.1029/2001JD000973.

Liousse, C., Michel, C., Bessagnet, B., Cachier, H., Rosset, R., 2005. 0D-Modelling of Carbonaceous Aerosols. Accepted for publication in $\mathrm{JOCH}$. 
Liousse, C., Penner, J.E., Chuang, C., Walton, J.J., Eddleman, H., Cachier, H., 1996. A global three-dimensional model study of carbonaceous aerosols. Journal of Geophysical Research 101, 19411-19432.

Mallet, M., Roger, J.C., Despiau, S., Dubovik, O., Putaud, J.P., 2003. Microphyscial and optical properties of aerosol particles in urban zone during ESCOMPTE. Atmospheric Research 69, 73-97.

Mallet, M., Roger, J.C., Despiau, S., Putaud, J.P., Dubovik, O., 2004. A method to study the mixing state of black carbon. Journal of Geophysical Research 109 (D4), D04202, doi:10.1029/2003JD003940.

Mallet, M., Dingenen, R.V., Roger, J.C., Despiau, S., Cachier, H., 2005a. In situ airborne measurements of aerosol optical properties during photochemical pollution events. Journal of Geophysical Research 110, D03205, doi:10.1029/ 2004JD005139.

Mallet, M., Pont, V., Liousse, C., 2005b. Strong heterogeneities in aerosol single scattering albedos over a polluted region. Geophysical Research Letters 32, L09807, doi:10.1029/ 2005 GL22680.

Marley, N.A., Gaffney, S.G., Baird, J.C., Blazer, C.A., Drayton, P.J., Frederick, J.E., 2001. An empirical method for the determination of the complex refractive index of size- fractionated atmospheric aerosols for radiative transfer calculations. Aerosol Science Technology 34, 535-549.

Mie G., 1908. Beiträge zur Optick trüber medien, speziell kolloidaler Metallösungen, Annalen Physik (Leipzig), vol. 25. pp. $377-445$.

Ramanathan, V., et al., 2001. The Indian experiment: an integrated assessment of the climate forcing and effects of the great Indo-Asian haze. Journal of Geophysical Research 106 (D22), 28,371-28,398.
Roger, J.C., Mallet, M., Dubuisson, P., Cachier, H., Vermote, E., Dubovik, O., Despiau, S., 2006. A synergetic approach for estimating the local direct aerosol forcing: Application to an urban zone during the Expérience sur Site pour Contraindre les Modèles de Pollution et de Transport d'Emission (ESCOMPTE) experiment. Journal of Geophysical Research 111, D13208, doi:10.1029/2005JD006361.

Scott, N.A., 1974. A direct method of computation of the transmission function of an inhomogeneous gaseous mediumI: Description of the method. Journal of Quantitative Spectroscopy and Radiative Transfer 14, 691-704.

Seinfeld, J.H., Pandis, S.N., 1998. From Air Pollution to Climate Change. Amospheric Chemistry and Physics. Wiley, New York, pp. 126.

Stamnes, K., Tsay, S., Wiscombe, W., Jayaweera, K., 1988. Numerically stable algorithm for discrete-ordinate-method radiative transfer in multiple scattering and emitting layered media. Applied Optics 27, 2502-2509.

Steiner, D., Burtchnew, H., Grass, H., 1992. Structure and disposition of particles from a spark ignition engine. Atmospheric Environment 26, 997-1003.

Vermote, E., Saleous, N.Z.El., Justice, C.O., Kaufman, Y.J., Privette, J., Remer, L.C., Tanré, D., 1997. Atmospheric correction of visible to middle infrared EOS-MODIS data over land surface, background, operational algorithm and validation. Journal of Geophysical Research 102 (14), 17131-17141.

Wu, Z.P., Wang, Y.P., 1991. Electromagnetic scattering for multilayered spheres: recursive Algorithms. Radio Science 26, 1393-1401.

Wu, X.A., Seigneur, C., Bergström, R.W., 1996. Evaluation of a sectional representation of size distributions for calculating aerosol optical properties. Journal of Geophysical Research 101 (D14), 19,277-19,283. 